\title{
Awareness of Premarital Screening and Genetic Counseling among Saudis and its Association with Sociodemographic Factors: a National Study
}

\author{
This article was published in the following Dove Press journal:
} Journal of Multidisciplinary Healthcare

\author{
Walid A Al-Shroby (D) ${ }^{1,2}$ \\ Suha M Sulimani ${ }^{3}$ \\ Sultana A Alhurishi ${ }^{4}$ \\ Maram E Bin Dayel' \\ Nora A Alsanie ${ }^{3}$ \\ Najla J Alhraiwil'
}

'Evaluation \& Impact Measurement Unit, Deputyship of Public Health, Ministry of Health, Kingdom of Saudi Arabia, Riyadh, Saudi Arabia; ${ }^{2}$ Public Health \&

Community Medicine Department, Faculty of Medicine, Beni-Suef University, Beni Suef, Egypt; ${ }^{3}$ Healthy Marriage Program, Deputyship of Public Health, Ministry of Health, Riyadh, Saudi Arabia; ${ }^{4}$ Community Health Sciences

Department, College of Applied Medical Sciences, King Saud University, Riyadh, Saudi Arabia
Correspondence: Najla J Alhraiwil; Walid A Al-Shroby

Evaluation \& Impact Measurement Unit, Deputyship of Public Health, Ministry of Health, Kingdom of Saudi Arabia, Riyadh, III76, Saudi Arabia

Tel +966566088I92; +966594707808

Email njalhraiwil@moh.gov.sa;

waamin@moh.gov.sa
Background: Premarital screening and genetic counseling (PMSGC) is compulsory in Saudi Arabia and aims to identify and decrease the prevalence of some genetic and sexually transmitted infectious diseases. However, there are little data on community awareness about PMSGC. This study assessed knowledge levels, attitudes, and behaviors associated with PMSGC in the general Saudi Arabian population and their associations with sociodemographic characteristics.

Methods: This was a cross-sectional, population-based study of 6263 participants randomly selected from all 20 health regions in Saudi Arabia, stratified according to age and fulfilling predefined selection criteria. Trained data collectors used a comprehensive pretested questionnaire to collect data. Data were collected in March and April 2019. Univariable and multivariable associations between sociodemographic characteristics and knowledge levels, attitudes, and behaviors were examined.

Results: While all 6263 study participants had heard about PMSGC, only 575 (9.2\%) participants had satisfactory knowledge, while 3283 (52.4\%) participants had fair knowledge. Predictors of high knowledge scores were university or higher education level $(\mathrm{aOR}=2.06$; 95\% CI: 1.80-2.36), positive medical history of PMSGC-screened disease $(\mathrm{aOR}=2.02$; 95\% CI: 1.51-2.69), family income $\geq 3000 \mathrm{SR} / \mathrm{month}(\mathrm{aOR}=1.70 ; 95 \% \mathrm{CI}$ : $1.50-1.93)$, being married/previously married $(\mathrm{aOR}=1.46 ; 95 \% \mathrm{CI}: 1.25-1.70)$, female gender $(\mathrm{aOR}=1.25 ; 95 \% \mathrm{CI}: 1.12-1.40)$, and age $>18$ years $(\mathrm{aOR}=1.25 ; 95 \% \mathrm{CI}: 1.06-1.48)$. The majority of participants $(5246,83.8 \%)$ had positive attitudes towards the importance of PMSGC, the burden of screened genetic and infectious diseases on the family, and that marrying was inadvisable with incompatible results. Of the 3986 engaged or married participants, 2911 (73.0\%) had undertaken premarital screening, of whom $360(12.4 \%)$ had incompatible results; 98 (37.1\%) married despite this information.

Conclusion: Despite advances in public healthcare measures in Saudi Arabia, gaps remain in the knowledge, beliefs, and behaviors associated with PMSGC. Culturally specific community health education programs for PMSGC must be devised that emphasize the risks associated with consanguineous marriage.

Keywords: premarital, screening, genetic counseling, consanguinity, Saudi Arabia

\section{Introduction}

Marriage is an important tradition in many cultures and for many is central to building healthy, happy, and stable family relationships. Premarital screening and genetic counseling (PMSGC), a consultation offered to individuals planning to marry, involves history taking, clinical examination, and laboratory investigations 
to screen for inherited and communicable diseases. PMSGC can therefore be a worthwhile preventative medicine approach. ${ }^{1}$

Hereditary diseases are highly prevalent in the general population of the Kingdom of Saudi Arabia (KSA) due to the high prevalence of consanguineous marriages. ${ }^{2}$ The overall prevalence of consanguinity in KSA is estimated to be $56 \%$, with a significantly higher prevalence in rural compared to urban areas. In KSA, first cousin relationships are more common than other types of relationship. ${ }^{3}$ As a consequence, Saudi Arabia has the highest prevalence of autosomal recessive disorders per capita in the world, ${ }^{4}$ and many studies have confirmed that consanguineous marriage increases the risk of genetic and hereditary diseases. ${ }^{5}$

Premarital reproductive carrier screening has been implemented in several countries and aims to inform adults about the risk of having children with genetic disorders. Until recently, public health prevention strategies for genetic diseases have focused on hemoglobinopathies (sickle cell anemia (SCA) and thalassemia). ${ }^{6}$ Saudi Arabia introduced the National Premarital Screening Program (NPSP) for sickle cell disease and thalassemia in 2001 and made it a mandatory step prior to receiving a marriage license in 2004. ${ }^{7}$ Through the NPSP, the Saudi Arabian government has made significant efforts to help protect future generations from the risk of hereditary diseases.

Premarital screening in KSA currently includes laboratory testing and medical consultation sessions for common genetic blood disorders (SCA and thalassemia) and infectious diseases (hepatitis $\mathrm{B}$, hepatitis $\mathrm{C}$, and HIV/AIDS). Screening takes place at over 131 healthcare centers across the Kingdom, and couples planning to marry must attend at least three months prior to the marriage date. Screening aims to determine the odds of transmitting these diseases to the other partner or children and to provide partners with options to plan for a healthy family. ${ }^{8}$

Community-based health education campaigns are an important way to encourage the public to improve their knowledge and attitudes towards the screening program, thereby encouraging healthy decision-making after obtaining the test results and consequently reducing the prevalence of infectious and genetic diseases in the country. ${ }^{5,9}$ The NPSP has therefore launched and implemented a national awareness campaign, the Healthy Marriage Campaign, to spread knowledge about genetic and infectious diseases and pre-marriage examination throughout the Kingdom.
Many studies have been conducted in Saudi Arabia to assess knowledge and attitudes towards pre-marital screening. However, these studies were either conducted in specific geographical regions ${ }^{10-13}$ or in specific populations (eg, university students). ${ }^{11,12}$ Thus, there is a need for nationwide data on knowledge and attitudes towards premarital screening in Saudi Arabia.

To address this knowledge gap, the objective of this study was to evaluate the knowledge, beliefs, and behaviors towards PMSGC in a large, randomly selected national sample of the Saudi population aged 15 years and over to identify associated sociodemographic factors that might assist stakeholders seeking to target education about the program.

\section{Materials and Methods}

Saudi Arabia has a population of $35,135,175$, of which $36.8 \%$ are non-Saudis. ${ }^{14}$ According to the Ministry of Justice, which is responsible for issuing marriage certificates, approximately 150,000 couples get married in the country each year. ${ }^{15}$ Saudi Arabia is divided into 13 administrative regions, which is divided by the Ministry of Health into 20 smaller health regions.

\section{Study Design, Setting, and Participants}

A descriptive cross-sectional population-based study was conducted as part of the NPSP to provide a national assessment of the level of knowledge, beliefs, and behaviors associated with PMSGC among a stratified random sample of the Saudi population aged 15 years and older.

Data were collected from the general population in schools, public venues, primary healthcare centers (PHCs), and mosques. Data were collected in March and April 2019.

The study sample was selected using a multi-stage stratified random sampling methodology with proportional allocation. The study sample was stratified according to the 20 Saudi health regions, age group, and then according to the sampling area. Thirty percent of the sample was aged 15-18 years and were contacted in schools; $60 \%$ of the sample was aged 19-50 years and were contacted in PHCs and public venues; and $10 \%$ of the sample was aged $>50$ years and were contacted in PHCs and mosques. This distribution was done to match the Saudi weight of age groups with special emphasis on the pre-marriage age group prior to 18 years.

The sample size was calculated using Epi Info STATCALC version 7.2.2.6, with assumptions based on 
Binshihon et al, who found that $48.9 \%$ of the unmarried population in western Saudi Arabia had fair to good knowledge about the premarital screening program. ${ }^{13}$ With a 95\% confidence level (CI), 5.5\% margin of error, $43 \%$ expected fair to satisfactory level of knowledge, and a design effect of 20 to permit analysis between the 20 regions, the sample size was calculated as 6220. Finally, 6250 people were targeted and 6500 were approached in case of sample attrition.

\section{Data Collection}

An interview questionnaire was developed to collect the required data based on a literature review. Some questionnaire items were borrowed from previously validated and published questionnaires, ${ }^{16-18}$ while other items were designed based on educational materials disseminated by the healthy marriage program to the public. The study questionnaire was developed in Arabic and reviewed by the research team and external experts for both face and content validity (mean individual and scale validity indices were $90 \%$ ). The questionnaire took 5-10 minutes to complete. Data collectors were trained and provided with tablets to collect the required data.

The study questionnaire covered the following variables: demographics: (region, gender, age, marital status, educational level, level of family income, parents' consanguinity, and life partner relationship); knowledge questions about genetic and infectious diseases (types, methods of transmission and infection, risk factors, symptoms, complications, and methods of prevention and treatment); knowledge questions about PMSGC (including its importance, sources of knowledge, places where screening is conducted, and the diseases covered by the program); beliefs questions (including beliefs about screening and the diseases covered by the program); and behavior questions (include screening, screening results, and decisionmaking after receiving the test results).

\section{Quantitative Variables}

A knowledge score was used to assess PMSGC knowledge levels, with correct answers encoded as one mark and incorrect answers and "don't know" answers encoded as zero. The PMSGC total knowledge score ranged from 0 to 39. The knowledge score was then transformed to a percentage of the maximum score. The percentage score was divided into three levels: $<50 \%$, poor knowledge; $50 \%-75 \%$, fair knowledge; and $>75 \%$, satisfactory knowledge.
Questions about beliefs and attitudes towards PMSGC contained five statements, and responses were coded as a 3-point Likert scale ( $0=$ disagree, $1=$ neutral, and $2=$ agree). These statements were measured by calculating a beliefs and attitudes score between 0 and 10, which was also transformed to a percentage of the maximum score and classified as: $<50 \%$, negative attitude; $50-75 \%$, neutral attitude; and $>75 \%$, positive attitude.

\section{Statistical Analysis}

The collected data were reviewed, coded, verified and statistically analyzed using SPSS v22 (IBM Statistics, Armonk, NY). Mean, standard deviation (SD), median, and interquartile range (IQR) were used to describe continuous data. Number $(\mathrm{N})$ and percentages were used to describe categorical data. The chi-squared test was used for comparisons of proportions. Odds ratios (OR) and 95\% confidence intervals (CI) were also calculated. The significant variables from bivariate analysis were used for multivariate logistic regression analysis through construction of a binary logistic regression model to identify predictors of a high knowledge score (fair and satisfactory). Adjusted odds ratio (aOR) and 95\% CI were calculated. Statistical significance was set at $\mathrm{p}<0.05$.

\section{Ethical Considerations}

The Central IRB of the Ministry of Health, Riyadh, Saudi Arabia approved the study protocol. All respondents provided consent prior to questionnaire administration. Parental informed consent for participants under the age of 18 years was waived, as the potential risk in this study was less than the minimum risk. The researchers informed participants about their right to withdraw from the study at any time without giving a reason and without risk of penalty. This study was conducted in accordance with the Declaration of Helsinki and all applicable local regulations. Data were stored securely and were only accessible by the research team.

\section{Results}

Of 6500 approached subjects, 6263 questionnaires were adequately completed and returned, a response rate of 96.4\%. Three thousand five hundred and forty-three (56.6\%) respondents were female, 3023 (48.3\%) were married, and 3739 (59.7\%) were aged between 19 and 50 years of age. Of the 3890 engaged, married, or previously married participants, 1890 (48.6\%) marriages were consanguineous. The majority of study subjects had 
a secondary school educational level (44.5\%) to university or higher (42.8\%). About half of respondents (47.8\%) had a monthly family income $<3000$ Saudi riyals (SR), and 2712 (43.3\%) had cousin parents. The prevalence of sickle cell anemia and thalassemia as reported by the study group was $1.4 \%$ and $1.2 \%$, respectively. The demographic characteristics of the study group are presented in Table 1.

All study participants had heard about PMSGC. Figure 1 shows the participants' sources of knowledge about the program. Regarding the total knowledge score, of 6263 participants, only 575 (9.2\%) had satisfactory knowledge about PMSGC and the screened genetic and infectious diseases, while 3283 participants $(52.4 \%)$ had fair knowledge and 2405 (38.4\%) had poor knowledge. The median total knowledge score was 21 (IQR 18-25).

Females and those married/previously married (divorced or widowed) were more likely to have fair and satisfactory PMS knowledge scores than males and those not previously married (single or engaged) $(65.2 \%$ and $72.7 \%$ vs $56.9 \%$ and $49.0 \%$, respectively; both $\mathrm{p}<$ 0.001). $70.1 \%$ of Saudis aged $>18$ years had fair and satisfactory knowledge scores compared to $42.9 \%$ of those aged $\leq 18$ years $(p<0.001)$. Those who were university educated or higher also had better knowledge scores ( $\mathrm{OR}=3.23 ; 95 \% \mathrm{CI}$ : 2.89-3.61). Knowledge scores increased significantly with increasing monthly family income. Participants with a history of any disease screened for in PMS also had a significantly higher level of knowledge compared to those with a negative history ( $\mathrm{OR}=$ 1.92; 95\% CI: 1.46-2.53) (Table 2).

Table 3 shows that all statistically significant crude associations between personal and sociodemographic factors and high knowledge scores persisted after adjustment. Having a university or higher education level was the first predictor of a high knowledge score $(\mathrm{aOR}=2.06 ; 95 \% \mathrm{CI}$ : 1.80-2.36), followed by a positive medical history of any disease screened for in PMSGC $(\mathrm{aOR}=2.02 ; 95 \% \mathrm{CI}$ : $1.51-2.69$ ), monthly family income $\geq 3000 \mathrm{SR}$ (aOR $=$ 1.70; 95\% CI: $1.50-1.93$ ), being married/previously married $(\mathrm{aOR}=1.46 ; 95 \% \mathrm{CI}: 1.25-1.70)$, female gender $(\mathrm{aOR}=1.25 ; 95 \% \mathrm{CI}: 1.12-1.40)$, and age $>18$ years $(\mathrm{aOR}=1.25 ; 95 \%$ CI: $1.06-1.48)$.

Figure 2 shows the attitudes of the study population towards the PMSGC program. The vast majority of participants $(94 \%$ and $91.7 \%)$ agreed that PMS reduces the incidence of some hereditary diseases and STDs and that couples were obliged to undertake PMS, respectively. $83.4 \%$ of study participants agreed that hereditary and
Table I Sociodemographic Characteristics of the Study Group $(\mathrm{n}=6263)$

\begin{tabular}{|c|c|c|}
\hline Characteristics & Number & Percentage \\
\hline \multicolumn{3}{|l|}{ Gender } \\
\hline Female & 3543 & 56.6 \\
\hline Male & 2720 & 43.4 \\
\hline \multicolumn{3}{|l|}{ Marital status } \\
\hline Single & 2373 & 37.9 \\
\hline Engaged & 571 & 9.1 \\
\hline Married & 3023 & 48.3 \\
\hline Divorced & 180 & 2.9 \\
\hline Widow & 116 & 1.9 \\
\hline \multicolumn{3}{|l|}{ Age group (yrs) } \\
\hline $15-18$ & 1949 & 31.1 \\
\hline $19-50$ & 3739 & 59.7 \\
\hline$>50$ & 575 & 9.2 \\
\hline \multicolumn{3}{|l|}{ Consanguinity } \\
\hline Single/not married before & 2373 & 37.9 \\
\hline Engaged or married before & 3890 & 62.1 \\
\hline - Consanguineous & 1890 & 48.6 \\
\hline - Not consanguineous & 2000 & 51.4 \\
\hline \multicolumn{3}{|l|}{ Education level } \\
\hline Illiterate & 95 & 1.5 \\
\hline Primary & 150 & 2.4 \\
\hline Preparatory & 550 & 8.8 \\
\hline Secondary & 2790 & 44.5 \\
\hline University or higher & 2678 & 42.8 \\
\hline \multicolumn{3}{|l|}{ Monthly family income } \\
\hline Less than $3000 \mathrm{SR}$ & 2994 & 47.8 \\
\hline From 3000 to 5999 SR & 768 & 12.3 \\
\hline From 6000 to 8999 SR & 708 & 11.3 \\
\hline From 9000 to 11,999 SR & 861 & 13.7 \\
\hline 12,000 or more SR & 932 & 14.9 \\
\hline \multicolumn{3}{|l|}{ Cousin parents } \\
\hline No & 3551 & 56.7 \\
\hline Yes & 2712 & 43.3 \\
\hline \multicolumn{3}{|c|}{$\begin{array}{l}\text { Medical history of any disease } \\
\text { screened in PMS* }\end{array}$} \\
\hline No & 5983 & 95.5 \\
\hline Yes & 280 & 4.5 \\
\hline Hepatitis B & 195 & 3.1 \\
\hline Thalassemia & 75 & 1.2 \\
\hline Hepatitis C & 32 & 0.5 \\
\hline Sickle cell anemia & 90 & $\mathrm{I} .4$ \\
\hline
\end{tabular}

Note: *More than one disease may have been selected. Abbreviations: PMS, premarital screening; SR, Saudi Riyal.

infectious diseases have a psychological and economic burden on the family, whilst $80.6 \%$ supported the idea to start awareness about premarital screening at the age of 15 


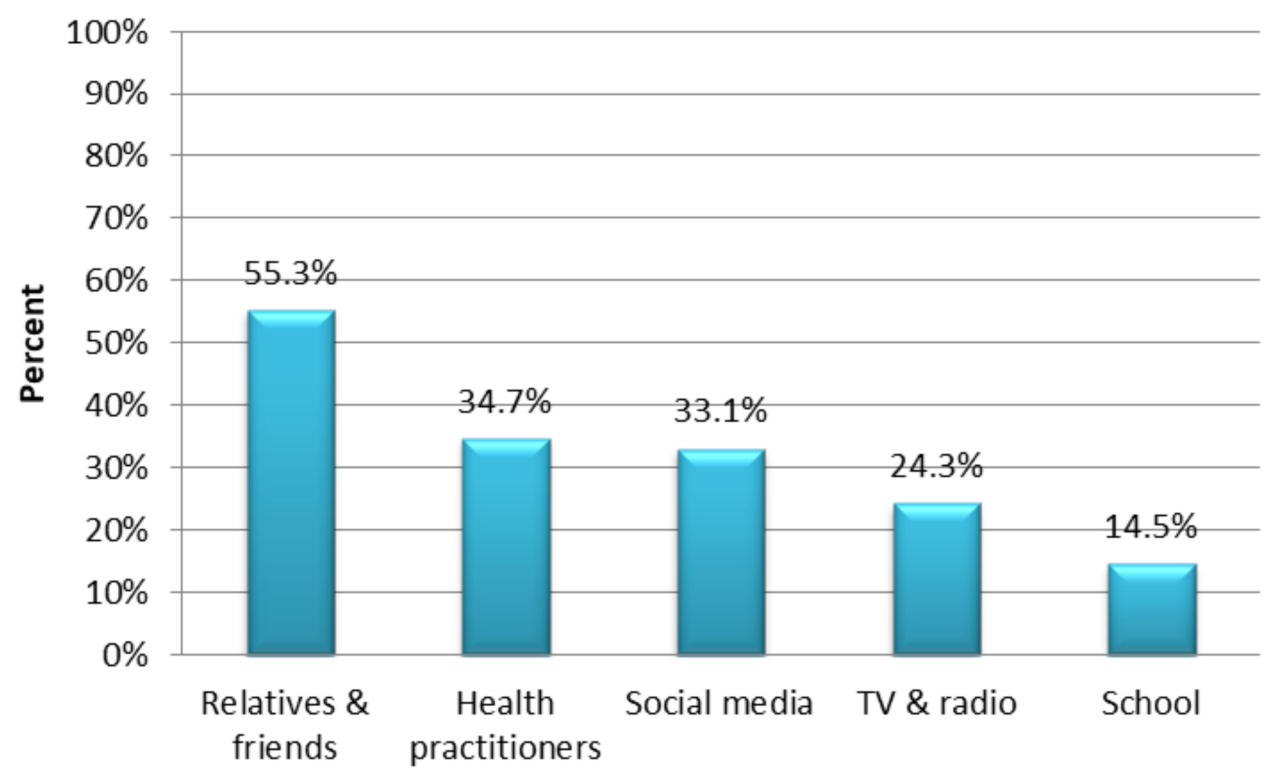

Figure I Sources of knowledge about the premarital screening program among the study population.

Note: More than one source may have been selected.

years. However, only $66.8 \%$ agreed that the decision to marry despite incompatible PMS results is inadvisable.

Four thousand three hundred and twenty-one (69\%) of the 6263 participants stated that positive premarital test results would affect their decision to marry. Regarding the most important reasons to ignore positive screening results and marry anyway, religious reasons (it being God's will) were most commonly reported $(1896,30.3 \%)$, followed by lack of awareness about the severity of the problem (1635, $26.1 \%)$, emotional reasons $(1158,18.5 \%)$, pressure from parents and society $(1046,16.7 \%)$, and sympathy for the other partner $(446,7.1 \%)$. Regarding the total attitude score, the majority of study participants $(5246,83.8 \%)$ had a positive attitude toward PMSGC and a minority had neutral or negative attitude $(13.3 \%$ and $2.9 \%$, respectively). The median score was 10 (IQR 8-10).

The relationships between the study population's attitude toward PMS and the studied variables are illustrated in Table 4. Married/previously married participants, those aged $>18$ years, those who had a university education or higher, and those who had a family income $\geq 3000$ SR/ month were significantly more likely to have a positive attitude compared to those not previously married, those aged $\leq 18$ years, those who had lower than a university education, and those who had a family income $<3000 \mathrm{SR} /$ month $(89.8 \%, 88.8 \%, 89.8 \%$ and $88.3 \%$ vs $77.0 \%$, $72.7 \%, 79.3 \%$ and $77.7 \%$, respectively; all $\mathrm{p}<0.001$ ). These associations persisted after adjusting for confounding variables, and gender, medical history of any disease screened for in PMS, and parental consanguinity showed no statistically significant association with attitudes toward PMS.

Regarding PMSGC practice, of 3986 engaged or married/previously married participants, 2911 (73.0\%) had undertaken premarital screening, of whom 360 (12.4\%) had incompatible results. Of these, 262 (72.8\%) refused to marry and $98(27.2 \%)$ married regardless of the test result.

There was a significant $(p<0.001)$ association between the practice of either completing or refusing to marry in cases of incompatible results and age; 15-18-year-olds had the best practice, with 142/166 (85.5\%) participants refusing to marry when the results were incompatible. In respondents $>50$ years, $8 / 14(57.1 \%)$ participants married despite having incompatible results.

There was also a significant $(\mathrm{p}<0.001)$ association between this practice and marital status, with the majority of divorced participants (11/12, 91.7\%) marrying with incompatible results and the majority of engaged participants $(111 / 150,74 \%)$ refusing to marry with incompatible results. This practice and educational level were also associated $(p<0.001)$, with the majority of illiterate and primary educated respondents marrying despite incompatible results and the majority with preparatory education or higher refusing to marry with incompatible results (Table 5). 
Table 2 Relationship Between Knowledge Levels About the Premarital Screening Program and Sociodemographic Factors in the Study Population

\begin{tabular}{|c|c|c|c|c|c|c|c|}
\hline \multirow[t]{2}{*}{ Knowledge Level Variable } & \multicolumn{2}{|l|}{ Poor } & \multicolumn{2}{|c|}{$\begin{array}{l}\text { Fair and } \\
\text { Satisfactory }\end{array}$} & \multirow[t]{2}{*}{ Total } & \multirow[t]{2}{*}{$\chi^{2}, \mathbf{P}$ value } & \multirow[t]{2}{*}{ OR, $95 \% \mathrm{Cl}$} \\
\hline & Number & $\%$ & Number & $\%$ & & & \\
\hline \multicolumn{8}{|l|}{ Gender } \\
\hline Female & 1233 & 34.8 & 2310 & 65.2 & 3543 & $44.7, p<0.001$ & $1.42,1.28-1.57$ \\
\hline Male & 1172 & 43.1 & 1548 & 56.9 & 2720 & & \\
\hline \multicolumn{8}{|l|}{ Marital status } \\
\hline Married before & 905 & 27.3 & 2414 & 72.7 & 3319 & $370.0, p<0.001$ & $2.77,2.49-3.08$ \\
\hline Not Married Before & 1500 & 51.0 & 1444 & 49.0 & 2944 & & \\
\hline \multicolumn{8}{|l|}{ Age (yrs) } \\
\hline$>18$ & 1292 & 29.9 & 3022 & 70.1 & 4314 & $418.6, p<0.001$ & $3.11,2.79-3.48$ \\
\hline$\leq 18$ & 1113 & 57.1 & 836 & 42.9 & 1949 & & \\
\hline \multicolumn{8}{|l|}{ Education level } \\
\hline University or higher & 626 & 23.4 & 2052 & 76.6 & 2678 & $446.5, p<0.001$ & $3.23,2.89-3.61$ \\
\hline Lower than University & 1779 & 49.6 & 1806 & 50.4 & 3585 & & \\
\hline \multicolumn{8}{|l|}{ Monthly family income } \\
\hline$\geq 3000 \mathrm{SR}$ & 892 & 27.3 & 2377 & 72.7 & 3269 & $357.1, p<0.001$ & $2.72,2.45-3.02$ \\
\hline$<3000$ SR & 1513 & 50.5 & $|48|$ & 49.5 & 2994 & & \\
\hline \multicolumn{8}{|l|}{ Cousin parents } \\
\hline Yes & 1060 & 39.1 & 1652 & 60.9 & 2712 & $0.95, p>0.05$ & $0.95,0.86-1.05$ \\
\hline No & 1345 & 37.9 & 2206 & 62.1 & 3551 & & \\
\hline \multicolumn{8}{|l|}{ Medical history of any disease screened for in PMS } \\
\hline Yes & 70 & 25.0 & 210 & 75.0 & 280 & $22.3, p<0.001$ & $1.92,1.46-2.53$ \\
\hline No & 2335 & 39.0 & 3648 & 61.0 & 5983 & & \\
\hline
\end{tabular}

Abbreviations: PMS, premarital screening; $\chi^{2}$, Chi square; OR, odds ratio; Cl, confidence interval; SR, Saudi Riyal.

\section{Discussion}

Current reform within the Saudi healthcare services emphasizes empowering individuals to promote healthy living and outcomes. PMSGC is a national screening program that aims to identify and reduce the burden of some genetic and sexually transmitted infectious diseases among high-risk groups by supporting their decision-making to limit transmission to their partner or future children. ${ }^{19}$ Despite the high prevalence of consanguineous marriages and hereditary diseases in Saudi Arabia, ${ }^{2-4}$ there is little research regarding community awareness about PMSGC within the general population. Here we addressed this knowledge gap.

This study assessed knowledge levels, attitude, and behaviors associated with PMSGC among a representative sample of the entire Saudi population and examined the relationships between these factors and associated sociodemographic characteristics (for example, gender, age, educational level, and marital status). In doing so, we provide up-to-date, evidence-based information to guide stakeholders seeking to promote healthy marriage and improve marriage outcomes.

Six thousand two hundred and sixty-three individuals participated in the study, and although all had heard about PMSGC, only 575 (9.2\%) had satisfactory knowledge about PMSGC and its related screened genetic and infectious diseases. This result is similar to a study from Oman, which showed that although most participants had heard about PMSGC, half were unaware of premarital testing. ${ }^{5}$

Our results are consistent with many previous studies conducted in Saudi Arabia, albeit in specific population groups. In one study, unmarried female university students had inadequate knowledge about PMSGC, with less than one-third of participants knowing which disorders are tested for and only $6.6 \%$ having satisfactory knowledge about PMSGC before completing a health education program. ${ }^{18}$ Another study assessed the knowledge of the Al-Madinah community about the PMS program and found that half were 
Table 3 Multiple Logistic Regression Analysis of Predictors of High Knowledge Score About the Premarital Screening Program Among the Studied Population

\begin{tabular}{|l|l|l|l|l|}
\hline Score and Variables & $\boldsymbol{\beta}$ & aOR & 95\% CI & $\mathbf{P}$ \\
\hline $\begin{array}{l}\text { PMS total knowledge } \\
\text { level } \\
\quad \text { University or higher } \\
\text { education level }\end{array}$ & 0.724 & 2.06 & $\mathrm{I} .80-2.36$ & $<0.000 \mathrm{I}$ \\
$\begin{array}{l}\text { Positive history of any } \\
\text { disease screened in PMS }\end{array}$ & $0.70 \mathrm{I}$ & 2.02 & $\mathrm{I} .5 \mathrm{I}-2.69$ & $<0.000 \mathrm{I}$ \\
$\begin{array}{l}\text { Family income } \geq 3000 \\
\text { SR/month }\end{array}$ & 0.529 & $\mathrm{I} .70$ & $\mathrm{I} .50-1.93$ & $<0.000 \mathrm{I}$ \\
$\begin{array}{l}\text { Being married before } \\
\text { Female gender }\end{array}$ & 0.376 & $\mathrm{I} .46$ & $\mathrm{I} .25-\mathrm{I} .70$ & $<0.000 \mathrm{I}$ \\
Age > I8 years & $0.22 \mathrm{I}$ & $\mathrm{I} .25$ & $\mathrm{I} .12-\mathrm{I} .40$ & $<0.000 \mathrm{I}$ \\
\hline Constant & 0.222 & $\mathrm{I} .25$ & $\mathrm{I} .06-1.48$ & 0.009 \\
\hline
\end{tabular}

Abbreviations: PMS, premarital screening; aOR, adjusted odds ratio; $\mathrm{Cl}$, confidence interval; SR, Saudi Riyal.

unaware of the screened diseases. ${ }^{12}$ In attendees of governmental outpatients clinics in Jeddah, knowledge about the PMSGC program was low. ${ }^{20}$ This gap in knowledge among participants highlights that more effort is needed to increase awareness about the PMSGC program by different means.

Over half of our participants gained their knowledge regarding PMSGC from relatives and/or friends, about a third from health practitioners, another third through the social media, and about one quarter gained their knowledge through TV and radio. This finding is similar to a study conducted in Jazan, Saudi Arabia, which reported that family, friends, and the internet were the main sources of information about PMSGC among Saudi students. ${ }^{17}$ Other studies have shown that the television represents a substantial source of information about PMSGC. ${ }^{20,21}$ The discrepancy between the current and previous studies may be due to a lack of television programs/televised health awareness campaigns raising awareness of PMSGC in KSA.

The current study found that education was the first predictor of a high PMSGC knowledge score, which is consistent with a previous study showing that individuals with a university degree or higher demonstrate a higher knowledge score. ${ }^{21}$ Another significant finding was that participants with a medical history of any disease screened for in PMSGC had better knowledge than those without. This is likely to be due to those suffering from these diseases being more aware of these diseases and their consequences and complications.

Higher family income was also a significant predictor, in agreement with findings from a recent study of the general population in western Saudi Arabia. ${ }^{13}$ We also detected an association between the level of PMSGC knowledge and marital status, with previously married participants having a higher knowledge score than those

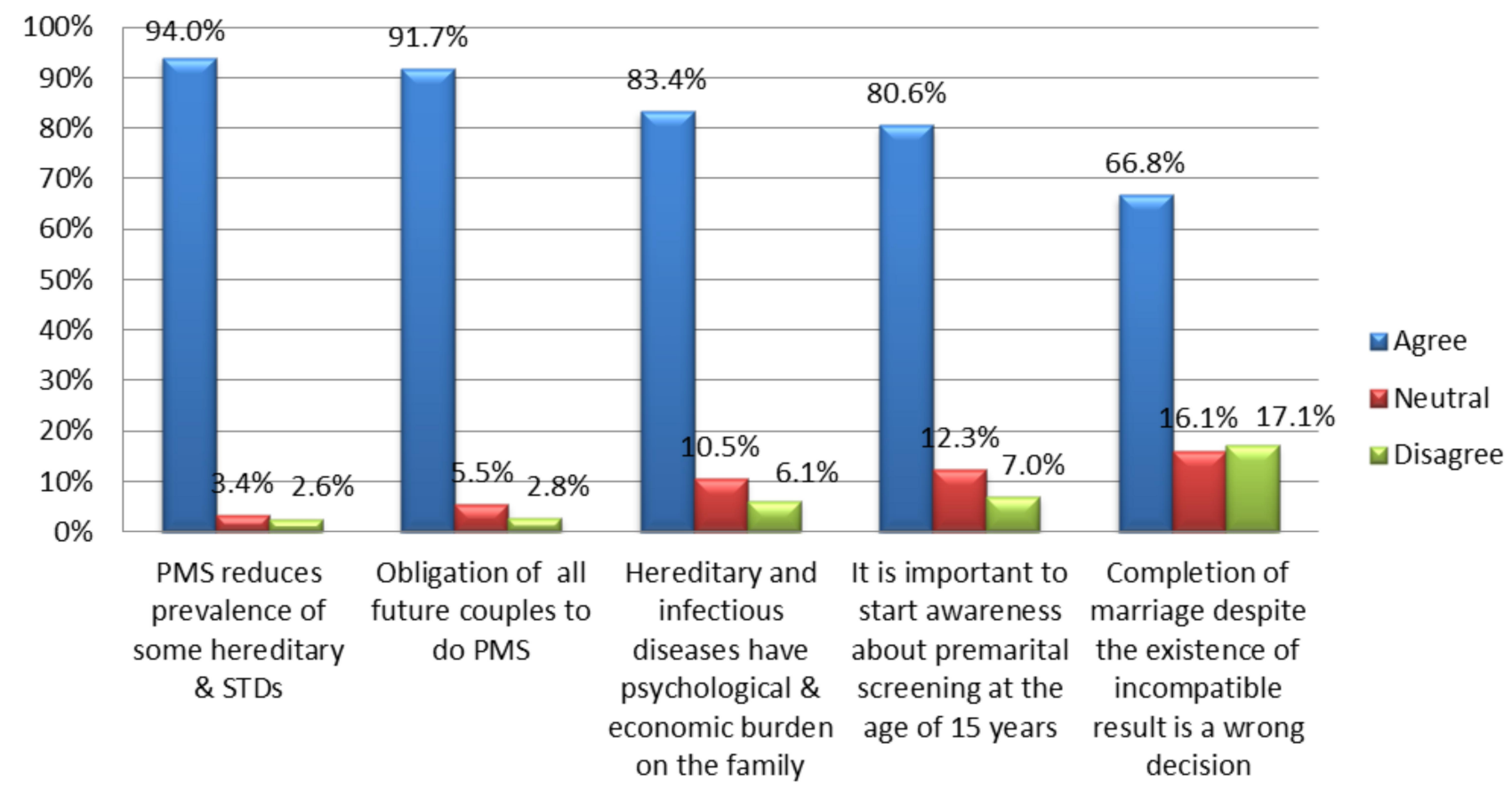

Figure 2 Attitudes toward the premarital screening program among the study population. Abbreviations: PMS, premarital screening; STDs, sexually transmitted diseases. 
Table 4 Relationship Between Attitude Toward the Premarital Screening Program and Sociodemographic Factors Among the Study Population

\begin{tabular}{|c|c|c|c|c|c|c|c|}
\hline \multirow[t]{2}{*}{ Attitude Level Variable } & \multicolumn{2}{|c|}{$\begin{array}{l}\text { Negative and } \\
\text { Neutral }\end{array}$} & \multicolumn{2}{|l|}{ Positive } & \multirow[t]{2}{*}{ Total } & \multirow[t]{2}{*}{$\chi^{2}, \mathbf{P}$} & \multirow[t]{2}{*}{ OR, $95 \% \mathrm{Cl}$} \\
\hline & Number & $\%$ & Number & $\%$ & & & \\
\hline \multicolumn{8}{|l|}{ Gender } \\
\hline Female & 567 & 16.0 & 2976 & 84.0 & 3543 & $0.33, p>0.05$ & $1.04,0.91-1.19$ \\
\hline Male & 450 & 16.5 & 2270 & 83.5 & 2720 & & \\
\hline \multicolumn{8}{|l|}{ Marital status } \\
\hline Married before & 339 & 10.2 & 2980 & 89.8 & 3319 & $188.4, p<0.001$ & $2.63,2.28-3.03$ \\
\hline Not Married Before & 678 & 23.0 & 2266 & 77.0 & 2944 & & \\
\hline \multicolumn{8}{|l|}{ Age (yrs) } \\
\hline$>18$ & 485 & 11.2 & 3829 & 88.8 & 4314 & $254.4, p<0.001$ & $2.96,2.58-3.40$ \\
\hline$\leq 18$ & 532 & 27.3 & 1417 & 72.7 & 1949 & & \\
\hline \multicolumn{8}{|l|}{ Education level } \\
\hline University or higher & 274 & 10.2 & 2404 & 89.8 & 2678 & $|24|,. p<0.00 \mid$ & $2.29,1.98-2.66$ \\
\hline Lower than university & 743 & 20.7 & 2842 & 79.3 & 3585 & & \\
\hline \multicolumn{8}{|l|}{ Monthly family income } \\
\hline$\geq 3000 \mathrm{SR}$ & 349 & 10.7 & 2920 & 89.3 & 3269 & $155.5, p<0.00 \mid$ & $2.40,2.09-2.77$ \\
\hline$<3000$ SR & 668 & 22.3 & 2326 & 77.7 & 2994 & & \\
\hline \multicolumn{8}{|l|}{ Cousin parents } \\
\hline Yes & 465 & 17.1 & 2247 & 82.9 & 2712 & $2.9, p>0.05$ & $0.89,0.78-1.02$ \\
\hline No & 552 & 15.5 & 2999 & 84.5 & 3551 & & \\
\hline \multicolumn{8}{|l|}{ Medical history of any disease screened in PMS } \\
\hline Yes & 57 & 20.4 & 223 & 79.6 & 280 & 3.7, $p>0.05$ & $0.75,0.55-1.01$ \\
\hline No & 960 & 16.0 & 5023 & 84.0 & 5983 & & \\
\hline
\end{tabular}

Abbreviation: PMS, premarital screening.

not married before. This is likely to be because these individuals had already attended premarital screening for married couples.

Females had a statistically significant greater knowledge about PMSGC than males. The reasons for this gender difference are unclear, but the result is consistent with that reported by Alhowiti et al, who found that female students were more knowledgeable about premarital screening than male students. ${ }^{22}$ However, no gender difference was observed in a recent study carried out in Qatar. ${ }^{23}$ This may be because women worry more about lifelong diseases that affect the quality of life of mothers and their children.

Recent health education initiatives to improve knowledge about hemoglobinopathies and premarital screening among secondary school and college students have reported promising results. ${ }^{24,25}$ Health education and awareness campaigns about the nature and value of PMSGC from credible sources are essential, but our results suggest that future health education programs should target men and single adults. In addition, health education messages should ensure that they are suitable for specific age groups and educational and socioeconomic backgrounds.

In the current study, the majority of participants $(83.8 \%)$ had a positive attitude towards the importance of PMSGC, the burden of screened genetic and infectious diseases on the family, and that it was the wrong decision to marry when the PMSG results were incompatible. AlSulaiman et al also found that the Saudi population was generally positive towards PMSGC, and the majority of participants agreed that the PMS program should apply to all couples in all regions of the Kingdom. ${ }^{26}$

In a study of female Saudi students, the majority of students had positive attitudes towards premarital screening. Most appreciated the severity of the diseases prevented by premarital screening and the benefits of premarital screening. ${ }^{27}$ This positive attitude could support healthcare workers during consultations with prospective 
Table 5 Relationship Between Marriage Behavior in Case of Incompatible PMS Results and Different Study Variables Among Engaged or Married/Previously Married Participants Undertaking Premarital Screening $(n=360)$

\begin{tabular}{|c|c|c|c|c|c|c|}
\hline \multirow[t]{2}{*}{ Marriage Behavior in Case of Incompatible PMS Results } & \multicolumn{2}{|c|}{$\begin{array}{l}\text { Completed } \\
\text { Marriage }\end{array}$} & \multicolumn{2}{|c|}{$\begin{array}{l}\text { Refused to Complete } \\
\text { Marriage }\end{array}$} & \multirow[t]{2}{*}{ Total } & \multirow[t]{2}{*}{$\chi^{2}, \mathbf{P}$} \\
\hline & Number & $\%$ & Number & $\%$ & & \\
\hline \multicolumn{7}{|l|}{ Gender } \\
\hline Female & 60 & 28.0 & 154 & 72.0 & 214 & $0.67, p>0.05$ \\
\hline Male & 38 & 26.0 & 108 & 74.0 & 146 & \\
\hline \multicolumn{7}{|l|}{ Marital status } \\
\hline Single & 0 & 0.0 & 96 & 100.0 & 96 & $82.73, p<0.001$ \\
\hline Engaged & 39 & 26.0 & 111 & 74.0 & 150 & \\
\hline Married & 44 & 48.9 & 46 & 51.1 & 90 & \\
\hline Divorced & 11 & 91.7 & 1 & 8.3 & 12 & \\
\hline Widow & 4 & 33.3 & 8 & 66.7 & 12 & \\
\hline \multicolumn{7}{|l|}{ Age (yrs) } \\
\hline $15-18$ & 24 & 14.5 & 142 & 85.5 & 166 & $28.08, p<0.001$ \\
\hline $19-50$ & 6 & 36.7 & 114 & 63.3 & 180 & \\
\hline$>50$ & 8 & 57.1 & 6 & 42.5 & 14 & \\
\hline \multicolumn{7}{|l|}{ Education level } \\
\hline Illiterate & 11 & 68.8 & 5 & 31.3 & 16 & $30.72, p<0.001$ \\
\hline Primary & 4 & 66.7 & 2 & 33.3 & 6 & \\
\hline Preparatory & 5 & 12.2 & 36 & 87.8 & 41 & \\
\hline Secondary & 40 & 21.2 & 149 & 78.8 & 189 & \\
\hline University or higher & 38 & 35.2 & 70 & 64.8 & 108 & \\
\hline \multicolumn{7}{|l|}{ Monthly family income } \\
\hline Less than $3000 \mathrm{SR}$ & 50 & 22.9 & 168 & 77.1 & 218 & $17.13, p<0.01$ \\
\hline From 3000 to 5999 SR & 13 & 37.1 & 22 & 62.9 & 35 & \\
\hline From 6000 to 8999 SR & 4 & 11.8 & 30 & 88.2 & 34 & \\
\hline From 9000 to II,999 SR & 19 & 46.3 & 22 & 53.7 & 41 & \\
\hline 12,000 or more SR & 12 & 37.5 & 20 & 62.5 & 32 & \\
\hline \multicolumn{7}{|l|}{ Cousin parents } \\
\hline No & 36 & 19.3 & $|5|$ & 80.7 & 187 & $12.48, p<0.001$ \\
\hline Yes & 62 & 35.8 & 111 & 64.2 & 173 & \\
\hline \multicolumn{7}{|l|}{ Medical history of any disease screened in PMS } \\
\hline No & 81 & 26.6 & 224 & 73.4 & 305 & $0.45, p>0.05$ \\
\hline Yes & 17 & 30.9 & 38 & 69.1 & 55 & \\
\hline
\end{tabular}

Abbreviation: PMS, premarital screening.

couples who might have a positive screening test. Future studies should further explore the association between attitudes and screening tests using theories related to decision-making and behavior change.

In the current study, attitudes towards PMSGC were associated with marital status, age, education level, and family income. Bener et al recently explored the knowledge, attitudes, and practices of Qataris towards a premarital screening program and reported similar results. $^{23}$
Regarding PMSGC practice in our participants, the majority of engaged, married, or previously married participants $(73.0 \%)$ performed premarital screening, of whom only $\sim 12 \%$ had incompatible results; $72.8 \%$ of these individuals refused to marry, while $27.2 \%$ married regardless of the test results. Additionally, there was a significant association between the decision to marry given positive results and age, marital status, and educational level.

Although the premarital screening program is compulsory, the outcome of the program with respect to reducing 
the burden of hemoglobinopathies nevertheless relies on the couple's subsequent decision to marry and have children. In a previous study, about two-thirds of students (67.1\%) agreed that when the test results revealed genetic diseases, the marriage decision should be changed. ${ }^{18} \mathrm{Al}$ Suliman et al also reported that $>60 \%$ of all Saudi participants were in favor of preventing at-risk marriages, similar to our results. ${ }^{28}$

AlQahtani et al found that of approximately $88.6 \%$ of participants agreeing to undergo elective pre-marital screening, $78.2 \%$ would not marry someone with SCA or thalassemia and $79.5 \%$ would not marry someone with a genetic trait if they themselves had a trait. ${ }^{20}$ Nevertheless, many individuals choose to proceed with marriage regardless of the results of premarital testing. ${ }^{29}$ Indeed, we found that $27.2 \%$ of participants decided to get married in spite of incompatible results. Therefore, the health benefits of the current program may need to be reinforced to ensure that the healthiest practices are adopted.

Consanguinity was common in married study participants $(48.6 \%)$ and also in the parents of study participants (43.3\%), consistent with existing data from Saudi Arabia. $^{22}$ The high prevalence of consanguineous marriage is likely to have an impact on the consequent prevalence of genetic disorders. ${ }^{27}$ Future research might consider exploring the quality of counselling and the impact of consanguinity in the context of decision-making following positive reproductive carrier screening.

To our knowledge, the current study is the first largescale community-based study conducted in all regions of Saudi Arabia on the knowledge, attitudes, and practice of the general population regarding the PMSGC program. However, the cross-sectional nature of the study makes causal inferences impossible. The results might have been different if another time frame had been chosen.

\section{Conclusion}

Overall knowledge about premarital screening tests needs to be improved. Considering that people have heard about the program and have a relatively positive attitude towards premarital screening, future health education campaigns and interventions would benefit from refinement by considering participant age, education level, and marital status. Additionally, monitoring hemoglobinopathies through screening and their relationship with consanguinity must be thoroughly investigated. Culture-specific interventions need to address consanguineous marriage practice and monitor its trend over time.

\section{Acknowledgments}

The authors would gratefully acknowledge the contribution of the health practitioners working in the Clinical Education Regional Departments for their help in collecting and providing the required data.

\section{Disclosure}

The authors report no conflicts of interest in this work.

\section{References}

1. Al-Kahtani NH. Acceptance of premarital health counseling in Riyadh city, 1417h. J Family Community Med. 2000;7(2):27-34.

2. Alam AA. Perception of female students of King Saud University towards premarital screening. J Family Community Med. 2006;13 (2):83-88.

3. Middle I, Al-Salloum AA, Al-Herbish AS, Qurachi MM, Al-Omar AA. Regional variations in the prevalence of consanguinity in Saudi Arabia. Saudi Med J. 2007;28(12):1881-1884.

4. Alkuraya FS. Genetics and genomic medicine in Saudi Arabia. Mol Genet Genomic Med. 2014;2(5):369-378. doi:10.1002/mgg3.97

5. Al-Farsi OA, Al-Farsi YM, Gupta I, et al. A study on knowledge, attitude, and practice towards premarital carrier screening among adults attending primary healthcare centers in a region in Oman. BMC Public Health. 2014;14(1):380. doi:10.1186/1471-2458-14-380

6. Delatycki MB, Alkuraya F, Archibald A, et al. International perspectives on the implementation of reproductive carrier screening. Prenat Diagn. 2020;40(3):301-310. doi:10.1002/pd.5611

7. Alsaeed ES, Farhat GN, Assiri AM, et al. Distribution of hemoglobinopathy disorders in Saudi Arabia based on data from the premarital screening and genetic counseling program, 2011-2015. J Epidemiol Glob Health. 2018;7(Suppl 1):S41-S47. doi:10.1016/j. jegh.2017.12.001

8. Saudi Ministry of Health. Premarital Screening; 2019. Available from: https://www.moh.gov.sa/en/HealthAwareness/Beforemarriage/ Pages/default.aspx. Accessed November 23, 2020.

9. Al Kindi R, Al Rujaibi S, Al Kendi M. Knowledge and attitude of university students towards premarital screening program. Oman Med J. 2012;27(4):291-296. doi:10.5001/omj.2012.72

10. Al-Qattan HM, Amlih DF, Sirajuddin FS, et al. Quantifying the levels of knowledge, attitude, and practice associated with sickle cell disease and premarital genetic counseling in 350 Saudi Adults. Adv Hematol. 2019;2019:3961201. doi:10.1155/2019/3961201

11. Al-Quwaidhi AJ, Almazroa MA. Saudi premarital screening program: public view after 3 years of implementation. Saudi Epidemiol Bull. 2008;15(3):19-20.

12. AlQahtani RS, Bedaiwi AA, Alburkani AM, et al. Knowledge and response of the community to premarital screening program (Sickle Cell Anemia/Thalassemia); AlMadinah, Saudi Arabia. $J$ Appl Hematol. 2018;9(2):59. doi:10.4103/joah.joah_1_18

13. Binshihon SM, Alsulami MO, Alogaibi WM, et al. Knowledge and attitude toward hemoglobinopathies premarital screening program among unmarried population in western Saudi Arabia. Saudi Med J. 2018;39(12):1226. doi:10.15537/smj.2018.12.23136

14. Saudi Arabia Population (2021) - worldometer; 2021. Available from: https://www.worldometers.info/world-population/saudi-arabiapopulation. Accessed January 28, 2021. 
15. General Authority for Statistics KSA. Statistical Yearbook of 2018; 2018. Available from: https://www.stats.gov.sa/en/1006. Accessed November 23, 2020.

16. Al-Aama JY, Al-Nabulsi BK, Alyousef MA, Asiri NA, Al-Blewi SM. Knowledge regarding the national premarital screening program among university students in western Saudi Arabia. Saudi Med J. 2008;29(11):1649-1653.

17. Hejri Y, Moussa M, Bushran S, Al-Mutairi K, Al-Harbi A. Evaluating premarital screening knowledge in Saudi students. Int J Commun Med Public Health. 2015;2:540-551. doi:10.18203/2394-6040. ijcmph20151045

18. Ibrahim NKR, Al-Bar H, Al-Fakeeh A, et al. An educational program about premarital screening for unmarried female students in King Abdul-Aziz University, Jeddah. J Infect Public Health. 2011;4 (1):30-40. doi:10.1016/j.jiph.2010.11.001

19. Gosadi IM. National screening programs in Saudi Arabia: overview, outcomes, and effectiveness. J Infect Public Health. 2019;12 (5):608-614. doi:10.1016/j.jiph.2019.06.001

20. Ibrahim NK, Bashawri J, Al Bar H, et al. Premarital screening and genetic counseling program: knowledge, attitude, and satisfaction of attendees of governmental outpatient clinics in Jeddah. $J$ Infect Public Health. 2013;6(1):41-54. doi:10.1016/j.jiph.20 12.05.001

21. Abd Al Azeem ST, Elsayed ET, El Sherbiny NAEK. Promotion of knowledge and attitude towards premarital care: an interventional study among medical student in Fayoum University. $J$ Public Health Epidemiol. 2011;3(3):121-128.

22. Alhowiti A, Shaqran T. Premarital screening program knowledge and attitude among Saudi University students in Tabuk city 2019. Int J Medl Res Health Sci. 2019;8(11):75-84.
23. Bener A, Al-Mulla M, Clarke A. Premarital screening and genetic counseling program: studies from an endogamous population. Int J Appl Basic Med Res. 2019;9(1):20-26. doi:10.4103/ijabmr. IJABMR $42 \quad 18$

24. Eissa M, Patel AA, Farag S, et al. Awareness and attitude of university students about screening and testing for hemoglobinopathies: case study of the Aseer Region, Saudi Arabia. Hemoglobin. 2018;42 (4):264-268. doi:10.1080/03630269.2018.1541802

25. Kotb MM, Almalki MJ, Hassan Y, et al. Effect of health education programme on the knowledge of and attitude about sickle cell anaemia among male secondary school students in the Jazan Region of Saudi Arabia: health Policy Implications. Biomed Res Int. 2019;2019:1-6. doi:10.1155/2019/9653092

26. Al Sulaiman A, Suliman A, Al Mishari M, Al Sawadi A, Owaidah TM. Knowledge and attitude toward the hemoglobinopathies premarital screening program in Saudi Arabia: population-based survey. Hemoglobin. 2008;32(6):531-538. doi:10.1080/03630260802508384

27. Khalil EMF, Abdelkader SM, Alsaeed MD, Alshahrany NM. Knowledge, beliefs and behavior intention about premarital screening among King Saud University female students in Riyadh. Sch J Appl Med Sci. 2014;2(5E):1797-1805.

28. Al Sulaiman A, Saeedi M, Al Suliman A, Owaidah T. Postmarital follow-up survey on high risk patients subjected to premarital screening program in Saudi Arabia. Prenat Diagn. 2010;30(5):478-481. doi: $10.1002 /$ pd.2507

29. Alhamdan NA, Almazrou YY, Alswaidi FM, Choudhry AJ. Premarital screening for thalassemia and sickle cell disease in Saudi Arabia. Genet Med. 2007;9(6):372-377. doi:10.1097/gim.0b013e318 $065 \mathrm{a} 9 \mathrm{e} 8$
Journal of Multidisciplinary Healthcare

\section{Publish your work in this journal}

The Journal of Multidisciplinary Healthcare is an international, peerreviewed open-access journal that aims to represent and publish research in healthcare areas delivered by practitioners of different disciplines. This includes studies and reviews conducted by multidisciplinary teams as well as research which evaluates the results or conduct of such teams or healthcare processes in general. The journal covers a very wide range of areas and welcomes submissions from practitioners at all levels, from all over the world. The manuscript management system is completely online and includes a very quick and fair peer-review system. Visit http://www.dovepress.com/testimonials. php to read real quotes from published authors. 